\title{
Konsep "Antargolongan" dalam Pasal 28 Ayat (2) Undang- Undang Nomor 19 Tahun 2016 Tentang Perubahan atas Undang-Undang Nomor 11 Tahun 2008 Tentang Informasi Dan Transaksi Elektronik (UU ITE)
}

\author{
Tiara Kumalasari \\ tiarakumalasari97@gmail.com \\ Universitas Airlangga
}

\begin{abstract}
Keywords: $\quad$ Abstract
Freedom of Speech; Factually, Article 28 paragraph (2) of Law Number 19 of 2016 concerning Amendment to Hate Speech; $\quad$ Law Number 11 of 2008 concerning Electronic Information and Transactions (UU ITE) "Intergroup" tends to be used to criminalize those who issue opinions in the form of criticism through Concept; Judge's electronic media because there is an unclear meaning of the concept of "intergroup" in Consideration. Article 28 paragraph (2) of the ITE Law so it causes different interpretations among law enforcement officials. This thesis aims to find clear criteria regarding the concept of "intergroup" contained in Article 28 Paragraph (2) of the ITE Law. The research method used is theoritical research, using statute approach, conceptual approach, and case approach. The conclusion is the consideration of judges in several court decisions, both the district court and the high court cannot give a clear meaning of the concept of "intergroup", even the Constitutional Court Decision also tends to expand it. With systematic interpretation, then in finding the criteria of the concept of "intergroup "In Article 28 paragraph (2) of the ITE Law may use the term "group" in Article 156 of the Criminal Code.
\end{abstract}

\begin{abstract}
Kata Kunci:
Abstrak

Kebebasan

Secara faktual, Pasal 28 Ayat (2) Undang-Undang Nomor 19 Tahun 2016 tentang Mengeluarkan Perubahan Atas Undang-Undang Nomor 11 Tahun 2008 tentang Informasi Pendapat; Ujaran dan Transaksi Elektronik (UU ITE). Adanya fakta bahwa Pasal 28 ayat (2) Kebencian; Konsep UU ITE cenderung digunakan untuk mengkriminalisasi orang-orang yang "Antargolongan"; ketidakjelasan makna dari konsep "antargolongan" dalam Pasal 28 ayat (2) UU Pertimbangan ITE sehingga menyebabkan penafsiran yang berbeda-beda di kalangan aparat Hakim. penegak hukum. Metode penelitian yang digunakan adalah penelitian hukum teoritikal (theoritical research) dengan menggunakan pendekatan perundangundangan (statute approach), pendekatan konseptual (conceptual approach), dan pendekatan kasus (case approach). Kesimpulannya adalah pertimbangan hakim dalam beberapa putusan pengadilan, baik pengadilan negeri maupun pengadilan tinggi tidak dapat memberikan makna yang jelas dari konsep "antargolongan", bahkan Putusan Mahkamah Konstitusi pun cenderung memperluasnya. Dengan penafsiran sistematis, maka dalam menemukan kriteria dari konsep "antargolongan" dalam Pasal 28 ayat (2) dapat digunakan istilah "golongan" dalam Pasal 156 KUHP.
\end{abstract}


Tiara Kumalasari: Konsep “Antargolongan" dalam...

\section{Pendahuluan}

Di Indonesia banyak terjadi kasus penyebaran informasi bermuatan ujaran kebencian berdasarkan atas suku, agama, ras, dan antargolongan. Berdasarkan catatan dari ICJR (Institute for Criminal Justice Reform), di tahun 2017 terdapat 46 kasus yang dilaporkan ke kepolisian dan 27 kasus yang dibawa ke persidangan dengan menggunakan ketentuan Pasal 28 ayat (2) UU ITE, sedangkan di tahun 2018 terdapat 41 kasus yang dilaporkan ke kepolisian dan 35 kasus yang dibawa ke persidangan dengan menggunakan Pasal 28 ayat (2) UU ITE. ${ }^{1}$

Pada dasarnya, Pasal 28 ayat (2) UU ITE ini bertujuan untuk mencegah terjadinya permusuhan dan perpecahan berbasis suku, agama, ras, dan antargolongan dikarenakan isu SARA merupakan isu yang sangat sensitif di masyarakat sehingga adanya informasi yang bersifat provokatif dan mengandung kebencian berkaitan dengan hal tersebut dapat menimbulkan permusuhan.

Beberapa contoh kasus yang dijerat oleh Pasal 28 ayat (2) UU ITE di antaranya:

1. Kasus Dandhy Dwi Laksono yang merupakan jurnalis dan aktivis dilaporkan oleh Dewan Pimpinan Daerah Relawan Perjuangan Demokrasi (Repdem) Jawa Timur yang merupakan organisasi sayap PDI-P ke Polda Jatim pada tanggal 6 September 2017 atastuduhan penghinaan melalui Facebook terhadap Ketua Umum PDI-P Megawati Soekarnoputri dan Presiden Jokowi. Ia mengunggah status yang pada pokoknya menyamakan kepemimpinan Megawati dengan Penasihat Negara Myanmar yang bernama Aung San Suu Kyi, terutama dalam hal mendukung kekerasan terhadap rakyat. $^{2}$ Ia juga menulis status terkait pernyataan Megawati mengenai petugas partai pada saat Jokowi terpilih sebagai presiden dan juga mengenai data 1.083 warga Papua yang ditangkap di pemerintahan Jokowi. ${ }^{3}$ Ia dituduh telah melanggar Pasal 28 ayat (2) UU ITE. Ia tidak membuat pernyataan yang menimbulkan kebencian berdasarkan suku, agama, dan ras, namun ia dituduh menyebabkan kebencian berdasarkan golongan, dalam hal ini adalah golongan pemerintah.

2. Kasus Robertus Robet yang merupakan seorang pengajar di Universitas

\footnotetext{
1 Anggara Suwahju, 'Menakar Makna “Antargolongan” Dalam Pasal 28 (2) UU ITE' (Beritagar.id, 2019) <https://beritagar.id/artikel-amp/telatah/menakar-makna-antar-golongandalam-pasal-28-2-uu-ite>. accessed 24 Agustus 2019.

2 Dian Kurniawan, 'Repdem Jatim Laporkan Dandhy Dwi Laksono Terkait Status Di FB' (Liputan6.com, 2017) <https://m.liputan6.com/regional/read/3085177/repdem-jatim-laporkandandhy-dwi-laksono-terkait-status-di-fb>. accessed 25 Oktober 2019.

3 Masfiatur Rochma, 'Samakan Megawati Dengan Aung San Suu Kyi, Dandhy Dwi Laksono Dipolisikan' (Merdeka.com, 2017) <https://m.merdeka.com/amp/peristiwa/samakan-megawatidengan-aung-san-suu-kyi-dandhy-dwi-laksono-dipolisikan.html>.accessed 25 Oktober 2019.
} 
Negeri Jakarta sekaligus aktivis HAM telah ditetapkan sebagai tersangka oleh Badan Reserse Kriminal Mabes Polri pada tanggal 6 Maret 2019 atas tunduhan telahmenyebarkan ujaran kebencian dalam sebuah video yang berisi orasinya di Aksi Kamisan yang menghina TNI dan mengkritik upaya dwifungsi TNI sehingga menuai kritik dan kontroversi di media sosial. Ia diduga melanggar Pasal 45A ayat (2) juncto Pasal 28 ayat (2) UU ITE dan Pasal 14 ayat (2) juncto Pasal 15 Undang-Undang Nomor 1 Tahun 1946 tentang Peraturan Hukum Pidana atau Pasal 207 KUHP yaitu menyebarkan informasi yang ditujukan untuk menimbulkan rasa kebencian atau permusuhan individu dan/atau kelompok masyarakat tertentu berdasarkan atas SARA dan berita bohong (hoax) atau penghinaan terhadap penguasa atau badan hukum yang ada di Indonesia. ${ }^{4}$ Dalam kasus tersebut, polisi memposisikan TNI sebagai identitas golongan tertentu. Hingga saat ini, kasus Robertus Robet masih dalam tahap penyidikan.

3. Kasus Ahmad Dhani yang menyebarkan 3 (tiga) cuitan melalui Twitter dengan nama akun @AHMADDHANIPRAST yang berisi ujaran kebencian kepada Ahok. Cuitan tersebut diunggah oleh admin Twitter Ahmad Dhani. Cuitancuitan tersebut antara lain "Yang menistakan agama si Ahok, yang diadili $\mathrm{KH}$ Ma'ruf Amin", "Siapa saja yang dukung penista agama adalah bajingan yang perlu diludahi mukanya", dan "Sila pertama Ketuhanan YME. Penista agama jadi gubernur, kalian waras?". ${ }^{5}$ Ia diduga melanggar Pasal 45A ayat (2) juncto Pasal 28 ayat (2) UU ITEjuncto Pasal 55 ayat (1) ke-1 KUHP yakni melakukan, yang menyuruh lakukan, dan yang turut serta melakukan perbuatan dengan sengaja dan tanpa hak menyebarkan informasi yang ditujukan untuk menimbulkan rasa kebencian atau permusuhan individu dan/atau kelompok masyarakat tertentu berdasarkan SARA. ${ }^{6}$ Dalam hal ini, golongan pendukung Ahok dimasukkan ke dalam kategori antargolongan. Kasus ini sudah diputus sampai tingkat kasasi pada tanggal 28 Agustus 2019.

4. Kasus penangkapan Faisol Abod Batis pada tanggal 10 Juli 2019 oleh Subdit II Direktorat Tindak Pidana Siber Bareskrim Polri karena disangka telah mengunggah konten di Instagram dengan nama akun @reaksirakyat1 yang berisi penghinaan terhadap Presiden Jokowi dan Polri, SARA, dan ujaran kebencian. Faisol dianggap telah menyinggung Jokowi dengan mengaitkannya dengan puluhan warga yang tewas pada kasus konflik agrarian tahun 20152018 dan menyinggung Polri yang gagal melindungi HAM saat aksi kerusuhan 21-22 Mei 2019. Ia diduga melanggar Pasal 45A ayat (2) juncto Pasal 28 ayat (2)

4 Dwi Rizki, 'Kasus Robertus Robet Kini Berstatus Dalam Penyidikan' (Wartakota.tribunnews. com, 2019) <https://wartakota.tribunnews.com/amp/2019/03/12/kasus-robertus-robet-kini-berstatus-dalam-penyidikan>. accessed 25 Oktober 2019.

5 Yandri Daniel Damaledo, 'Kasus-Kasus Hukum Yang Pernah Menjerat Ahmad Dhani' (Tirto.id, 2019) <https://amp.tirto.id/kasus-kasus-hukum-yang-pernah-menjerat-ahmad-dhanidfiB>. accessed 25 Oktober 2019.

6 Hestiana Dharmastuti, 'Perjalanan Kasus Ahmad Dhani Hingga Divonis 1,5 Tahun Penjara' (detikNews, 2019) <https://m.detik.com/news/berita/d-4403919/perjalanan-kasus-ahmad-dhani-hingga-divonis-15-tahun-penjara>. accessed 25 Oktober 2019. 
UU ITE dan/atau Pasal 16 juncto Pasal 4 huruf b Undang-Undang Nomor 40 Tahun 2008 tentang Penghapusan Diskriminasi Ras dan Etnis dan/atau Pasal 14 ayat (2) dan/atau Pasal 15 Undang-Undang Nomor 1 Tahun 1946 tentang Penyebaran Berita Bohong dan/atau Pasal 207 KUHP dan/atau Pasal 160 KUHP tentang penghinaan terhadap penguasa dan mengganggu ketertiban umum, padahal data yang dipaparkan sesuai dengan hasil riset lembaga Konsorsium Pembaruan Agraria (KPA). ${ }^{7}$ Dalam hal ini, presiden dan polisi dimasukkan ke dalam kategori antargolongan.

5. Kasus Bambang Tri Mulyono yang ditangkap oleh Bareskrim Polri pada tanggal 31 Desember 2016 karena telah menyebarkan informasi bermuatan ujaran kebencian terhadap Presiden Jokowi di dalam bukunya yang berjudul Jokowi Undercover. Dalam bukunya tersebut Bambang mengatakan bahwa Presiden Jokowi telah melakukan pemalsuan data pada saat mengajukan diri sebagai calon presiden 2014 lalu. Dalam bukunya juga disebutkan bahwa Desa Giriroto, Boyolali, merupakan basis Partai Komunis Indonesia terkuat se-Indonesia, padahal PKI sudah bubar sejak tahun 1966. Selain itu, ia juga menyebarkan kebencian terhadap kelompok masyarakat yang bekerja di dunia pers dengan menyebut Jokowi dan Jusuf Kalla muncul karena keberhasilan media massa dan melakukan kebohongan kepada rakyat. Tulisan yang ia buat tersebut tanpa disertai dokumen pendukung sehingga hanya merupakan persepsi pribadinya dan tidak akurat. ${ }^{8}$ Ia diduga melanggar Pasal 16 Undang-Undang Nomor 40 Tahun 2008 tentang Penghapusan Diskriminasi Ras dan Etnis dan Pasal 28 ayat (2) UU ITE. ${ }^{9}$ Dalam hal ini, presiden dimasukkan ke dalam kategori antargolongan. Kasus ini sudah diputus oleh Pengadilan Negeri.

6. Kasus penghinaan Presiden Jokowi dan penyebar ujaran kebencian di media sosial oleh Ropi Yatsman. Ia ditangkap Bareskrim Polri pada tanggal 27 Februari 2017 karena telah menyebarkan ujaran kebencian dengan mengedit foto Presiden Jokowi dan sejumlah pejabat, termasuk Ahok menggunakan akun Facebook bernama Agus Hermawan dan Yasmen Ropi. Ia diduga melangggar Pasal 45A ayat (2) juncto Pasal 28 ayat (2) UU ITE. ${ }^{10}$ Dalam hal ini, presiden dan pejabat negara dimasukkan ke dalam kategori antargolongan. Kasus ini sudah diputus oleh Majelis Hakim Pengadilan Negeri Lubukbasung, Kabupaten Agam, Sumatera Barat pada tanggal 24 Juli 2017

7. Kasus Muhammad Faizal Tanong yang ditangkap oleh Direktorat Tindak

7 Adhi Wicaksono, 'Kaitkan Jokowi Dengan Konflik Agraria, Faisol Diciduk Polisi' (CNN Indonesia, 2019) <https://m.cnnindonesia.com/nasional/20190717131806-12-412902/kaitkan-jokowi-dengan-konflik-agraria-faisol-diciduk-polisi>. accessed 25 Oktober 2019.

8 Ihsanuddin, 'Penghina Presiden Diproses Polisi, Ini Kata Istana' (Kompas.com, 2017) <https://nasional.kompas.com/read/2017/01/02/16523081/penghina.presiden.diproses.polisi. ini.kata.istana?page=2>. accessed 25 Oktober 2019.

9 Ambaranie Nadia Kemala Movanita, 'Penulis Buku “Jokowi Undercover" Ditangkap Dan Ditahan Polisi' (Kompas.com, 2016) <https://nasional.kompas.com/read/2016/12/31/12423041/ penulis.buku.jokowi.undercover.ditangkap.dan.ditahan.polisi>.accessed 25 Oktober 2019.

10 Altas Maulana, 'Penghina Presiden Jokowi Divonis 13 Bulan Penjara' (Antaranews.com, 2017)<https:/ / m.antaranews.com/berita/642423/ penghina-presiden-jokowi-divonis-15-bulan-penjara>. accessed 25 Oktober 2019. 
Pidana Siber Bareskrim Polri pada tanggal 20 Juli 2017 karena telah menyebarkan berita hoax dan ujaran kebencian melalui akun Facebook-nya. Dalam akunnya tersebut terdapat gambar-gambar dan tulisan yang berisi cacian dan fitnah terhadap Presiden Jokowi, partai politik, organisasi kemasyarakatan, kepolisian, dan agama tertentu. Unggahan-unggahan Faizal yang bermuatan hoax dan ujaran kebencian di antaranya yaitu gambar yang menyebutkan bahwa Kapolri Tito Karnavian adalah dalang adu domba Banser NU dengan Hizbut Tahrir Indonesia, gambar Presiden Jokowi dengan keterangan bahwa Presiden Jokowi anti Islam, pro PKI dan banyak ingkar janji, dan masih banyak lagi. Unggahan-unggahan tersebut tidak disertai bukti-bukti termasuk hoax. Ia diduga melanggar Pasal 45A ayat (2) juncto Pasal 28 ayat (2) UU ITE dan/atau Pasal 16 juncto Pasal 4 huruf b angka 1 Undang-Undang Nomor 40 Tahun 2008 tentang Penghapusan Diskriminasi Ras dan Etnis. ${ }^{11}$ Dalam hal ini, presiden, polisi, partai politik, dan organisasi kemasyarakatan dimasukkan ke dalam kategori antargolongan. Kasus ini sudah diputus oleh Pengadilan Negeri Jakarta Utara.

8. Kasus Sri Rahayu Ningsih yang merupakan pengurus grup Saracen ditangkap pada tanggal 5 Agustus 2017. Seperti yang telah diketahui, grup Saracen merupakan sarana untuk menyebarkan ujaran kebencian berbasis SARA. Ia ditangkap karena telah menyebarkan konten berbau SARA di akun Facebook pribadinya. Selain itu, ia juga mengunggah puluhan foto-foto dan tulisan dengan konten bermuatan ujaran kebencian dan penghinaan terhadap Presiden Jokowi, berbagai partai, organisasi kemasyarakatan dan kelompok, serta menyebarkan konten hoax lainnya di akun Facebook pribadinya yang bernama Sri Rahayu Ningsih atau Nyonya Sasmita. Ia diduga telah melakukan ujaran kebencian dengan konten SARA sebagaimana dimaksud dalam Pasal 45A ayat (2) juncto Pasal 28 ayat (2) UU ITE dan/atau Pasal 16 juncto Pasal 4 huruf $\mathrm{b}$ angka 1 Undang-Undang Nomor 40 Tahun 2008 tentang Penghapusan Diskriminasi Ras dan Etnis dan/atau Pasal 156 KUHP. ${ }^{12}$ Dalam hal ini, presiden, partai politik, dan organisasi kemasyarakatan dimasukkan ke dalam kategori antargolongan. Kasus ini sudah diputus oleh Majelis Hakim Pengadilan Negeri Cianjur.

9. Kasus Buni Yani yang ditetapkan tersangka oleh Ditkrimsus Polda Metro Jaya pada tanggal 23 November 2016 menyebarkan dan mengedit video pidato Ahok terkait Surat Al Maidah sehingga menimbulkan kegaduhan. Editan video tersebut dianggap menimbulkan makna yang berbeda sehingga dapat menimbulkan kebencian atau permusuhan. Ia diduga melanggar Pasal 32 ayat

${ }^{11}$ Heru Andriyanto, 'Ini Isi Akun Faizal Tonong Yang Membuatnya Ditangkap' (Beritasatu. com, 2017) <https://amp.beritasatu.com/nasional/442894/ini-isi-akun-faizal-tonong-yang-membuatnya-ditangkap>.accessed 25 Oktober 2019.

${ }^{12}$ Ambaranie Nadia Kemala Movanita, 'Sri Rahayu Yang Ditangkap Terkait Konten SARA Adalah Anggota Saracen' (Kompas.com, 2017) <https://amp.kompas.com/nasional/ $\mathrm{read} / 2017 / 08 / 24 / 10060611 /$ sri-rahayu-yang-ditangkap-terkait-konten-sara-adalah-anggota-saracen>.accessed 25 Oktober 2019. 
(1) UU ITE dan Pasal 28 ayat (2) UU ITE. Dalam hal ini, Ahok selaku Gubernur DKI Jakarta (pemerintah) pada saat itu dimasukkan ke dalam kategori antargolongan. Kasus ini sudah diputus oleh Pengadilan Negeri Bandung, akan tetapi pada tingkat banding dan kasasi, permohonannya ditolak. ${ }^{13}$

10.Kasus Burhanudin, seorang santri pesantren di Kecamatan Pasrepan, Pasuruan yang ditangkap dan oleh Tim Cyber Crime Polda Jawa Timur pada tanggal 7 Juni 2017. Ia ditetapkan menjadi karena telah membuat gambar meme di dalam akun Facebook-nya yang bernama Elluek Ngangenniee. Konten yang dibuat berisi penghinaan terhadap petinggi Polri hingga kepala negara, salah satunya yaitu Presiden Jokowi yang digambarkan sebagai tukang tambal ban. Ia diduga melanggar Pasal 45A ayat (2) juncto Pasal 28 ayat (2) UU ITE. Dalam hal ini, petinggi Polri dan kepala negara dimasukkan ke dalam kategori antargolongan. Setelah menjalani pemeriksaan intensif, pada tanggal 10 Juni 2017, ia dibebaskan dan dipulangkan. ${ }^{14}$

11.Kasus seorang pegawai kontrak PT Telkom Kendari yang bernama Nursalam yang ditangkap oleh anggota Cyber Crime Ditreskrimsus Polda Sulawesi Tenggara pada tanggal 4 Juni 2017. Ia ditetapkan menjadi tersangka karena membuat status di Facebook bermuatan penghinaan terhadap Kapolri Jenderal Tito Karnavian. Ia juga turut membuat status bermuatan penghinaan dan ujaran kebencian terhadap Presiden Jokowi dan salah satu partai politik yang dapat memicu konflik SARA. AKBP Soenarto selaku Kabid Humas Polda Sulawesi Tenggara mengatakan bahwa penangkapan terhadap Nursalam dilakukan setelah menemukan status Facebook Nursalam yang dapat menimbulkan kebencian atau permusuhan antarindividu, suku, dan agama. ${ }^{15}$ Ia diduga melanggar Pasal 45A ayat (2) juncto Pasal 28 ayat (2) UU ITE atau Pasal 45 ayat (3) juncto Pasal 27 ayat (3) UU ITE. Dalam hal ini, kapolri, presiden, dan partai politik dimasukkan ke dalam kategori antargolongan. ${ }^{16}$

Pasal 28 ayat (2) UU ITE sangat potensial menimbulkan kesulitan dalam penerapannya dikarenakan mengandung aturan hukum yang kabur (vage normen) yang terdapat pada konsep "antargolongan". Pasal tersebut tidak memberikan penjelasan yang jelas dan tegas mengenai makna dan kriteria

${ }^{13}$ Luthfia Ayu Azanella, 'Selain Ahmad Dhani, Ini Daftar Orang Yang Divonis Karena Terjerat UU ITE' (Kompas.com, 2019) <https:/ / nasional.kompas.com/read/2019/01/30/18493331/selainahmad-dhani-ini-daftar-orang-yang-divonis-karena-terjerat-uu-ite?page=3 $>$.accessed 25 Oktober 2019.

14 Achmad Faizal, ‘Buat Meme Menghina Presiden Di Facebook, Seorang Pemuda Ditangkap' (Kompas.com, 2017) <https://regional.kompas.com/read/2017/06/09/16265591/buat.meme. menghina.presiden.di.facebook.seorang.pemuda.ditangkap>.accessed 25 Oktober 2019.

${ }^{15}$ Kiki Andi Pati, ‘Diduga Hina Presiden Dan Kapolri Di Facebook, Seorang Pegawai Kontrak Ditahan' (Kompas.com, 2017) <https://regional.kompas.com/read/2017/06/06/16232091/diduga. hina.presiden.dan.kapolri.facebook.seorang.pegawai.kontrak.ditahan>. accessed 25 Oktober 2019.

${ }^{16}$ Kiki Andi Pati, 'Pria Ini Disebut Hina Presiden Dan Kapolri Di Facebook Sejak 2016' (Kompas.com, 2017) <https://regional.kompas.com/read/2017/06/07/05463681/pria.ini.disebut.hina. presiden.dan.kapolri.di.facebook.sejak.2016>.accessed 25 Oktober 2019. 
dari konsep "antargolongan" sehingga pasal tersebut dapat menimbulkan penafsiran yang berbeda-beda, yang mana dapat ditafsirkan secara meluas atau menyempit. Contoh tafsir meluas yaitu orang yang hendak mengeluarkan pendapatnya berupa kritikan kepada pemerintah melalui media elektronik, tidak menutup kemungkinan dapat dianggap sebagai ancaman dan dapat dilaporkan menggunakan pasal tersebut, sedangkan contoh tafsir menyempit yaitu konsep "antargolongan" dapat saja diartikan sebagaimana yang dimaksud oleh Pasal 163 IS, yaitu pembagian golongan penduduk menjadi golongan Eropa, golongan Timur Asing, dan golongan Bumiputera. Berbeda halnya dengan suku, agama, dan ras yang memang sudah jelas maknanya.

Dengan adanya pemaknaan yang terlalu luas tersebut dapat menimbulkan pertanyaan, apakah golongan seperti golongan partai politik, golongan pejabat, golongan pendukung gubernur, golongan pendukung presiden, golongan disabilitas, dan sebagainya juga termasuk golongan yang dimaksud dalam Pasal 28 ayat (2) UU ITE. Sedangkan dalam hukum pidana terdapat prinsip lex certa, lex stricta, dan lex scripta. Menurut Jan Remmelink, lex certa artinya perumusan perbuatan pidana dalam undang-undang harus diuraikan unsur-unsurnya secara jelas dan rinci, lex stricta artinya harus didefinisikan secara jelas dan rigid tanpa samar-samar sehingga tidak ada perumusan yang ambigu mengenai suatu perbuatan pidana, sedangkan lex scripta artinya perumusan perbuatan pidana harus dituangkan secara tertulis dalam suatu perundang-undangan. ${ }^{17}$

Berdasarkan uraian tersebut, maka perlu untuk dikaji lebih lanjut mengenai kriteria dari konsep "antargolongan" agar tidak menimbulkan penafsiran yang berbeda-beda sehingga pasal tersebut dapat digunakan secara lebih presisi dan tepat yang dapat secara efektif memberikan rasa keadilan,tetapi di sisi lain juga tidak membunuh (membungkam) kebebasan warga negara untuk mengeluarkan pendapat.

17 Agustinus Pohan, Topo Santoso, Dan Martin Moerings, Hukum Pidana Dalam Perspektif (Pustaka Larasan 2012).[43-44]. 
Tiara Kumalasari: Konsep "Antargolongan" dalam...

\section{Kebebasan Mengeluarkan Pendapat dan Pembatasannya}

Setiap orang memiliki kebebasan untuk mengeluarkan pendapatnya. Pada awalnya, kebebasan mengeluarkan pendapat diatur di dalam Deklarasi Universal Hak Asasi Manusia (DUHAM) yang disetujui oleh Majelis Dewan PBB pada tanggal 10 Desember 1948. Kebebasan mengeluarkan pendapat ini diatur di dalam Pasal 19 DUHAM yang menyatakan bahwa "Setiap orang berhak atas kebebasan memiliki dan mengeluarkan pendapat; dalam hal ini termasuk kebebasan memiliki pendapat tanpa gangguan dan untuk mencari, menerima dan menyampaikan informasi dan buah pikiran melalui media apa saja dan dengan tidak memandang batas-batas wilayah."18 Kebebasan mengeluarkan pendapat merupakan hak asasi dan hak konstitusional setiap warga negara yang pelaksanaannya harus dijamin dan dijunjung tinggi oleh negara sehingga dilindungi dengan cara diatur di dalam peraturan perundang-undangan tertinggi di negara Indonesia yaitu di dalam Undang-Undang Dasar Negara Republik Indonesia Tahun 1945 (UUD NRI 1945) yakni Pasal 28E ayat (3) dan 28F. Pasal 28E ayat (3) UUD NRI 1945 menyatakan bahwa : "Setiap orang berhak atas kebebasan berserikat, berkumpul dan mengeluarkan pendapat." Sedangkan Pasal 28F UUD NRI 1945 menyatakan bahwa :

"Setiap orang berhak untuk berkomunikasi dan memperoleh informasi untuk mengembangkan pribadi dan lingkungan sosialnya, serta berhak untuk mencari, memperoleh, memiliki, menyimpan, mengolah, dan menyampaikan informasi dengan menggunakan segala jenis saluran yang tersedia".

Selain itu, kebebasan mengeluarkan pendapat juga diatur di dalam undangundang, di antaranya di dalam Pasal 2 Undang-Undang Nomor 9 Tahun 1998 tentang Kemerdekaan Menyampaikan Pendapat di Muka Umum, Pasal 14 ayat (2) dan Pasal 23 ayat (2) Undang-Undang Nomor 39 Tahun 1999 tentang Hak Asasi Manusia, Pasal 4 ayat (1) Undang-Undang Nomor 40 Tahun 1999 tentang Pers, Pasal 19 ayat (2) Undang-Undang Nomor 12 Tahun 2005 tentang Pengesahan

\footnotetext{
${ }^{18}$ Edmon Makarim, Kompilasi Hukum Telematika (PT RajaGrafindo Persada 2003).[191].
} 
International Covenant on Civil and Political Rights (Kovenan Internasional tentang Hak-Hak Sipil dan Politik).

Hak menyatakan pendapat merupakan hak yang tidak dapat dikurangi, tetapi menurut sejumlah pasal dalam ICCPR menyatakan bahwa hak menyatakan pendapat merupakan hak yang dapat dibatasi (derogable right) jika dinilai dapat membahayakan keselamatan negara. Berdasarkan Pasal 20 ayat (2) ICCPR, hak berbicara dan berpendapat dapat dibatasi jika pendapat yang dilakukan menganjurkan kebencian atas dasar kebangsaan, ras dan agama yang merupakan hasutan untuk melakukan diskriminasi, permusuhan atau kekerasan. Selain itu, berdasarkan Pasal 28J UUD 1945, kebebasan berpendapat juga dibatasi oleh kewajiban untuk menghormati hak asasi orang lain.

Kebebasan menyatakan pendapat melalui teknologi informasi dalam penggunaan dan pemanfaatannya dapat dibatasi dengan mempertimbangkan pembatasan yang telah ditetapkan undang-undang dengan tujuan untuk menjamin pengakuan serta penghormatan atas hak dan kebebasan orang lain dan untuk memenuhi tuntutan yang adil sesuai dengan pertimbangan moral, nilainilai agama, keamanan, dan ketertiban umum dalam suatu masyarakat yang demokratis. ${ }^{19}$

Teknologi informasi merupakan kebutuhan masyarakat saat ini yang tidak dapat dibendung. Di samping dapat memberikan banyak manfaat bagi peningkatan kesejahteraan dan kemajuan masyarakat, namun di sisi lain teknologi informasi dapat digunakan sebagai sarana yang efektif untuk melakukan perbuatan melawan hukum. Undang-Undang Nomor 11 Tahun 2008 tentang Informasi dan Transaksi Elektronik sebagaimana telah diubah dengan Undang-Undang Nomor 19 Tahun 2016 tentang Perubahan Atas Undang-Undang Nomor 11 Tahun 2008 tentang Informasi dan Transaksi Elektronik (UU ITE) merupakan payung hukum negara Indonesia pertama dalam bidang Informasi dan Transaksi Elektronik. Dalam Penjelasan Umum UU ITE terbaru disebutkan bahwa diperlukan penegasan

19 Penjelasan Umum Undang-Undang Republik Indonesia Nomor 19 Tahun 2016 Tentang Perubahan Atas Undang-Undang Nomor 11 Tahun 2008 Tentang Informasi Dan Transaksi Elektronik. 
Tiara Kumalasari: Konsep "Antargolongan" dalam...

peran pemerintah dalam mencegah penyebarluasan konten ilegal yang memiliki muatan melanggar hukum guna melindungi kepentingan umum dari segala jenis gangguan akibat penyalahgunaan Informasi dan Transaksi Elektronik. Konten ilegal yang dimaksud seperti adanya Informasi dan/atau Dokumen Elektronik yang memiliki muatan yang melanggar kesusilaan, perjudian, penghinaan atau pencemaran nama baik, pemerasan dan/atau pengancaman, penyebaran berita bohong dan menyesatkan sehingga mengakibatkan kerugian konsumen dalam Transaksi Elektronik, serta perbuatan menyebarkan kebencian atau permusuhan berdasarkan suku, agama, ras, dan golongan, dan pengiriman ancaman kekerasan atau menakut-nakuti yang ditujukan secara pribadi. ${ }^{20}$

\section{Undang-Undang tentang Informasi dan Transaksi Elektronik}

UU ITE merupakan salah satu tindak pidana khusus karena dalam UU ITE telah mengatur sendiri tentang tindak pidana dan ketentuan pidana di bidang informasi dan transaksi elektronik yang berbeda dengan KUHP karena dilakukan mengenai proses hukum acara pidananya tetap mengacu kepada KUHAP. ${ }^{21}$

UU ITE merupakan produk legislasi yang sangat dibutuhkan dan telah menjadi pionir yang meletakkan dasar pengaturan di bidang pemanfaatan Teknologi Infomasi dan Transaksi Elektronik. ${ }^{22}$ Penyusunan materi UU ITE terdiri dari 2 (dua) naskah akademik, yang pertama yaitu RUU Pemanfaatan Teknologi Informasi (RUU PTI) yang disusun oleh Universitas Padjajaran yang ditunjuk oleh Departemen Komunikasi dan Informasi dengan melakukan kerjasama dengan para pakar dari Institut Teknologi Bandung. Naskah akademik yang kedua yaitu RUU Informasi Elektronik dan Transaksi Elektronik yang disusun oleh Universitas Indonesia yang ditunjuk oleh Departemen Perindustrian dan Perdagangan. Kemudian kedua naskah akademik dilakukan penggabungan dan disesuaikan

\footnotetext{
20 ibid.

${ }^{21}$ Didik Endro Purwoleksono, Hukum Pidana: Untaian Pemikiran (Airlangga University Press 2019).[5].

${ }^{22}$ Danrivanto Budhijanto, Revolusi Cyberlaw Indonesia Pembaruan Dan Revisi Undang-Undang Informasi Dan Transaksi Elektronik 2016 (PT Refika Aditama 2017).[8].
} 
kembali oleh tim yang dipimpin Prof. Ahmad M Ramli SH atas nama pemerintah Susilo Bambang Yudhoyono yang dinamakan menjadi Undang-Undang Informasi dan Transaksi Elektronik sebagaimana disahkan oleh DPR. ${ }^{23}$

UU ITE diundangkan pertama kali pada tanggal 21 April 2008, sedangkan perubahannya diundangkan pada tanggal 25 November 2016. Komitmen pemerintah untuk melahirkan suatu produk khusus di bidang informasi dan transaksi elektronik dapat dikatakan sebagai jawaban terhadap keprihatinan yang timbul dalam praktik penegakan hukum di bidang telematika.

\section{Pasal 28 Ayat (2) UU ITE}

Pasal 28 ayat (2) UU ITE menyatakan bahwa : "Setiap Orang dengan sengaja dan tanpa hak menyebarkan informasi yang ditujukan untuk menimbulkan rasa kebencian atau permusuhan individu dan/atau kelompok masyarakat tertentu berdasarkan atas suku, agama, ras, dan antargolongan (SARA)." Sedangkan untuk ancaman pidananya diatur di dalam Pasal 45A ayat (2) UU ITE yakni “Setiap Orang yang dengan sengaja dan tanpa hak menyebarkan informasi yang ditujukan untuk menimbulkan rasa kebencian atau permusuhan individu dan/ atau kelompok masyarakat tertentu berdasarkan atas suku, agama, ras, dan antargolongan (SARA) sebagaimana dimaksud dalam Pasal 28 ayat (2) dipidana dengan pidana penjara paling lama 6 (enam) tahun dan/atau denda paling banyak Rp 1.000.000.000,00 (satu miliar rupiah)".

Selain UU ITE, dalam undang-undang hukum pidana lain juga terdapat pasal-pasal serupa terkait penyebaran kebencian, di antaranya:

1. Kitab Undang-Undang Hukum Pidana (KUHP)

a. Pasal $156 \mathrm{KUHP}$ :

"Barangsiapa di muka umum menyatakan perasaan permusuhan, kebencian atau penghinaan terhadap suatu atau beberapa golongan rakyat Indonesia, diancam dengan pidana penjara paling lama empat tahun atau pidana denda paling banyak tiga ratus rupiah. Perkataan golongan dalam

${ }^{23}$ Ihsan Hidayat, 'Undang-Undang Informatika Dan Transaksi Elektronik' (Academia.edu) <https://www.academia.edu/37952527/TUGAS_TI_ihsan_hidayat>.accessed 9 November 2019. 
Tiara Kumalasari: Konsep “Antargolongan” dalam...

pasal ini dan pasal berikutnya berarti, tiap-tiap bagian rakyat Indonesia, yang berbeda dengan suatu atau beberapa bagian lainnya karena rasnya, negeri asalnya, agamanya, tempat asalnya, keturunannya, kebangsaannya atau kedudukannya menurut hukum tata negara".

b. Pasal 157 KUHP:

“(1) Barang siapa menyiarkan, mempertunjukkan atau menempelkan di muka umum, tulisan atau lukisan yang isinya mengandung pernyataan perasaan permusuhan, kebencian atau penghinaan di antara atau terhadap golongan-golongan rakyat Indonesia, dengan maksud supaya isinya diketuhui atau lebih diketahui oleh umum, diancam dengan pidana penjara paling lama dua tahun enam bulan atau pidana denda paling banyak tiga ratus rupiah.

(2) Jika yang bersalah, melakukan kejahatan tersebut pada waktu menjalankan pencarian, dan pada saat itu belum lewat lima tahun sejak adanya pemidanaan yang menjadi tetap, karena kejahatan semacam itu juga, maka dapat dilarang menjalankan pencarian tersebut."

2. Pasal 4 Undang-Undang Nomor 40 Tahun 2008 tentang Penghapusan Diskriminasi Ras dan Etnis :

“Tindakan diskriminatif ras dan etnis berupa :

a. memperlakukan pembedaan, pengecualian, pembatasan, atau pemilihan berdasarkan pada ras dan etnis, yang mengakibatkan pencabutan atau pengurangan pengakuan, perolehan, atau pelaksanaan hak asasi manusia dan kebebasan dasar dalam suatu kesetaraan di bidang sipil, politik, ekonomi, sosial, dan budaya; atau

b. menunjukkan kebencian atau rasa benci kepada orang karena perbedaan ras dan etnis yang berupa perbuatan :

1. membuat tulisan atau gambar untuk ditempatkan, ditempelkan, atau disebarluaskan di tempat umum atau tempat lainnya yang dapat dilihat atau dibaca oleh orang lain;

2. berpidato, mengungkapkan, atau melontarkan kata-kata tertentu di tempat umum atau tempat lainnya yang dapat didengar orang lain;

3. mengenakan sesuatu pada dirinya berupa benda, kata-kata, atau gambar di tempat umum atau tempat lainnya yang dapat dibaca oleh orang lain; atau

4. melakukan perampasan nyawa orang, penganiayaan, pemerkosaan, perbuatan cabul, pencurian dengan kekerasan, atau perampasan kemerdekaan berdasarkan diskriminasi ras dan etnis." 
Unsur-unsur dalam Pasal 28 ayat (2) UU ITE dapat diuraikan sebagai berikut:

1. Unsur "setiap Orang"

2. Unsur "dengan sengaja dan tanpa hak"

3. Unsur "menyebarkan informasi"

4. Unsur "untuk menimbulkan rasa kebencian atau permusuhan"

5. Unsur "terhadap individu dan/atau kelompok masyarakat tertentu"

6. Unsur "berdasarkan suku, agama, ras, dan antargolongan (SARA)"

\section{Pertimbangan Hakim}

Berikut ini merupakan beberapa pertimbangan hakim Pengadilan Negeri dalam memaknai konsep "antargolongan" dalam perkara-perkara yang dijerat Pasal 28 ayat (2) UU ITE :

1. Kasus Ahmad Dhani sudah diputus hingga tingkat kasasi. Di Pengadilan Negeri Jakarta Selatan dengan nomor putusan 370/Pid.Sus/2018/PN Jkt. Sel tanggal 28 Januari 2019, ia terbukti secara sah dan meyakinkan bersalah melakukan tindak pidana dengan sengaja dan tanpa hak menyuruh lakukan menyebarkan informasi yang ditujukan untuk menimbulkan rasa kebencian atau permusuhan individu dan/atau kelompok berdasarkan atas SARA sehingga ia divonis pidana penjara selama 1 (satu) tahun 6 (enam) bulan, lalu pada tingkat banding di Pengadilan Tinggi DKI Jakarta dengan nomor putusan 58/Pid.Sus/2019/PT.DKI tanggal 13 Maret 2019, ia divonis dengan pidana penjara menjadi 1 (satu) tahun. Pada tingkat kasasi, Majelis Hakim Mahkamah Agung menolak kasasi Ahmad Dhani dan penuntut umum dengan alasan bahwa alasan-alasan kasasi yang diajukan oleh kedua belah pihak tidak dapat dibenarkan karena putusan Pengadilan Tinggi DKI Jakarta dalam pertimbangan dan penerapan hukumnya sudah benar dengan melakukan perbaikan terhadap ancaman pidana penjara yang sebelumnya dijatuhkan oleh Pengadilan Negeri Jakarta Selatan selama 1 (satu) tahun 6 (enam) bulan menjadi 1 (satu) tahun. Selain itu, MA berpendapat bahwa unsur-unsur 
pelanggaran yang dilakukan oleh Ahmad Dhani telah terbukti secara sah. ${ }^{24}$ Dikarenakan Putusan Pengadilan Tinggi DKI Jakarta pada pokoknya hanya merubah vonis pidana penjara, namun selebihnya menguatkan Putusan Pengadilan Negeri Jakarta Selatan, maka pertimbangan hukum hakim yang dijadikan acuan ialah pertimbangan hukum hakim pada Putusan Pengadilan Negeri Jakarta Selatan. Berikut merupakan pertimbangan hukum hakim dalam Putusan Pengadilan Negeri Jakarta Selatan Nomor 370/Pid.Sus/2018/ PN Jkt.Sel terkait pemaknaan dari kata "antargolongan" yang terdapat dalam Pasal 28 ayat (2) UU ITE :

a. Bahwa saat cuitan Ahmad Dhani menghasilkan komentar, baik pro maupun kontra, dapat disimpulkan bahwa cuitan tersebut bersifat provokatif karena berdampak pada terbentuknya kelompok yang saling berbeda posisinya dan dapat mengarah kepada konflik terbuka bersifat SARA;

b. Secara sosiologis, unsur suku dan ras dapat menyangkut Ahok yang merupakan orang Tionghoa, unsur agama adalah orang-orang yang dianggap anti Islam, dan unsur antargolongan adalah golongan yang mendukung Ahok sebagai calon Gubernur DKI Jakarta.

Jadi, menurut majelis hakim, golongan pendukung gubernur atau dapat dikatakan pendukung pemerintah dimasukkan ke dalam kategori "antargolongan" Pasal 28 ayat (2) UU ITE. Selain itu, pemaknaan “antargolongan" menurut para ahli yang didatangkan ke persidangan kasus ini antara lain:

a. Ahli Setyo Untoro, S.S., M.Hum menerangkan bahwa pengertian antargolongan ialah antargolongan atau kelompok yang satu dan yang lain, misalnya, golongan mayoritas dan golongan minoritas.

b. Ahli Drs. Krisanjaya, M.Hum menerangkan bahwa pengertian golongan

24 Andrian Pratama Taher, 'Mahkamah Agung Tolak Permohonan Kasasi Ahmad Dhani' (Tirto.id, 2019) <https:/ / tirto.id/ mahkamah-agung-tolak-permohonan-kasasi-ahmad-dhani-ehdn>. accessed 27 Oktober 2019. 
adalah hasil menggolong-golongkan, tidak ada syarat untuk menjadi golongan. Selain itu, juga diterangkan bahwa golongan yang dimaksud dalam kasus ini ialah golongan yang menista agama atau golongan pendukung Ahok.

c. Ahli Dr. Effendy Saragih, S.H., M.H. (ahli pidana) menerangkan bahwa pengertian antargolongan ialah antara golongan yang satu dengan golongan yang lain. Selain itu, juga diterangkan bahwa antargolongan adalah kumpulan masyarakat yang memiliki kesamaan, baik formal maupun non formal.

2. Kasus Muhammad Faizal Tanong sudah diputus oleh Pengadilan Negeri Jakarta Utara dengan nomor putusan 1105/Pid.Sus/2017/PNJkt.Utr tanggal 18 Desember 2017. Ia terbukti secara sah dan bersalah melakukan tindak pidana Pasal 28 ayat (2) UU ITE. Ia divonis pidana penjara selama 1 (satu) tahun 6 (enam) bulan dan denda sebesar Rp 200.000.000,00 (dua ratus juta rupiah) subsider pidana kurungan selama 3 (tiga) bulan. Dalam pertimbangan hukum hakim Pengadilan Negeri Jakarta Utara tidak menjelaskan secara eksplisit mengenai makna antargolongan, namun dapat dikaitkan dengan cara menganalisis tiap tulisan yang ditulis oleh Faizal yaitu :

a. Terhadap tulisan "27 fakta indikasi Jokowi adalah kader dan keturunan PKI", hakim memposisikan presiden, massa, pengikut, simpatisan, kelompok pendukung Jokowi, dan partai politik sebagai antargolongan;

b. Terhadap tulisan “Terkuak, Kapolri Tito Karnavian adalah dalang adu domba Banser NU dengan Hizbuth Tahrir Indonesia", hakim memposisikan aparat penegak hukum sebagai antargolongan;

c. Terhadap beberapa tulisan yang ditujukan untuk pemimpin NU Saiq Aqil Siraj yakni "Warga NU sejati kok pada diem dipimpin kyai sesat dan menyesatkan begini.. sok moderat tapi ucapan dan pernyataan tidak cerminkan seorang kyai bijak" dan "Orang ini sengaja disusupkan untuk hancurkan NU dari dalam hingga dibenci umat Islam", hakim memposisikan pemimpin NU termasuk dalam kategori antargolongan. 


\section{Putusan Mahkamah Konstitusi Nomor 76/PUU-XV/2017}

Pasal 28 ayat (2) UU ITE telah dilakukan uji materiil ke Mahkamah Konstitusi pada tanggal 28 Maret 2018. Pemohon mengajukan permohonan untuk menguji konstitusionalitas frasa "dan antargolongan" yang terdapat di dalam Pasal 28 ayat (2) UU ITE dan Pasal 45A ayat (2) UU ITE. Pokok permohonan para Pemohon adalah ketidakjelasan makna dari istilah atau frasa "dan antargolongan" serta ketiadaan batasan dari istilah atau frasa "dan antargolongan". Pemohon mendalilkan bahwa pasal tersebut merugikan hak konstitusionalnya karena berpotensi dijadikan alat untuk mengkriminalisasi pemohon. Dalam amarnya, MK menolak permohonan pemohon untuk seluruhnya, namun MK dalam Putusan Mahkamah Konstitusi Nomor 76/PUU-XV/2017 tanggal 28 Maret 2018 telah memberikan pertimbangan mengenai penafsiran "antargolongan" dalam Pasal 28 ayat (2) UU ITE sebagai berikut: "Mahkamah mempertegas bahwa istilah 'antargolongan' tidak hanya meliputi suku, agama, dan ras, melainkan lebih dari itu yaitu semua entitas yang tidak terwakili atau terwadahi oleh istilah suku, agama, dan ras".

Kritik Terhadap Putusan Kasus Ahmad Dhani, Muhammad Faizal Tanong, dan Putusan Mahkamah Konstitusi

1. Putusan Pengadilan Negeri Jakarta Selatan Nomor 370/Pid.Sus/2018/PN Jkt. Sel (Ahmad Dhani)

Dalam kasus ini, hakim hanya memberikan pertimbangan dengan memasukkan entitas pendukung gubernur ke dalam kategori "antargolongan" dalam Pasal 28 ayat (2) UU ITE. Selain itu, para ahli juga turut memberikan definisi antargolongan yakni sebatas kelompok yang satu dengan kelompok yang lain serta kumpulan masyarakat yang memiliki kesamaan, baik formal maupun non formal. Pertimbangan hakim dalam kasus ini tidak jelas karena tidak memiliki alasan/penjelasan dalam memasukkan entitas pendukung gubernur termasuk ke dalam kategori "antargolongan".

2. Putusan Pengadilan Negeri Jakarta Utara Nomor 1105/Pid.Sus/2017/PNJkt. Utr (Muhammad Faizal Tanong) 
Dalam kasus ini, tidak memberikan definisi mengenai istilah "antargolongan", melainkan hanya memasukkan suatu entitas ke dalam kategori "antargolongan", misalnya, presiden, pendukung presiden, partai politik, aparat penegak hukum, pemimpin NU, dan sebagainya dimasukkan ke dalam kategori antargolongan. Pertimbangan hakim dalam kasus ini tidak jelas karena tidak memiliki alasan/penjelasan dalam memasukkan entitas pendukung gubernur termasuk ke dalam kategori "antargolongan". Hakim hanya menjabarkan tiap tulisan Faizal dan sasaran dari tulisan tersebut langsung dimasukkan ke dalam kategori "antargolongan".

3. Putusan Mahkamah Konstitusi Nomor 76/PUU-XV/2017

Menurut Mahkamah Konstitusi, yang dimaksud dengan istilah “antargolongan" dalam Pasal 28 ayat (2) UU ITE ialah tidak hanya meliputi suku, agama, dan ras, melainkan lebih dari itu yaitu semua entitas yang tidak terwakili atau terwadahi oleh istilah suku, agama, dan ras. Pendapat Mahkamah Konstitusi tersebut tidak jelas karena justru memperluas definisi "antargolongan", bukan memberikan definisi yang jelas dan tegas.

Dari beberapa putusan di atas telah tercermin ketidakjelasan dari aturan hukum yang ada yaitu Pasal 28 ayat (2) UU ITE sebab masih menimbulkan penafsiran yang berbeda-beda dan terlalu luas oleh hakim. Ketidakjelasan dari Pasal 28 ayat (2) UU ITE tersebut tidak mencerminkan asas legalitas, khususnya lex certa karena perumusan Pasal 28 ayat (2) UU ITE tidak diuraikan unsur-unsurnya secara jelas dan rinci.

\section{Hukum Antargolongan}

Hukum antargolongan adalah keseluruhan peraturan atau keputusan hukum yang menunjukkan hukum manakah yang berlaku, dalam hubungan hukum antara warga negara dalam satu negara. Pada mulanya, hukum antargolongan terdapat pada masa Hindia Belanda yang dikenal dengan istilah 
Tiara Kumalasari: Konsep "Antargolongan" dalam...

intergentiel recht, interpersonal law, interracial law. ${ }^{25}$ Hukum antargolongan timbul sebagai akibat dari politik Pemerintah Kolonial Belanda yang pada prinsipnya ingin memecah belah bangsa Indonesia. Hukum antargolongan tersebut yakni pembagian golongan penduduk Indonesia serta pembagian sistem hukum yang berlaku bagi golongan penduduk tersebut. Hal tersebut diatur di dalam Pasal 163 IS (Indische Staatsregeling) juncto Pasal 131 IS yakni: ${ }^{26}$

1. Golongan Eropa, yang meliputi :
a. Belanda;
b. Bukan Belanda tetapi dari Eropa;
c. Jepang;
d. Lain-lain yang hukum keluarganya sama dengan Belanda, Amerika, Australia, dan lainnya;
e. Keturunan dari keempat golongan di atas.

Terhadap golongan ini berlaku:
a. Hukum perdata menggunakan BW (Burgerlijk wet Boek) dan WvK (Wetboek van Koophandel);
b. Hukum pidana menggunakan Wvs (Wetboek van Strafrecht);
c. Hukum acara perdata menggunakan Reglement of de Burgerlijke, sedangkan hukum acara pidana menggunakan Reglement of Straf vor dering.

2. Golongan Timur Asing, yang meliputi :
a. Cina;
b. Bukan Cina (India, Arab).

Terhadap golongan ini berlaku:

a. Khusus untuk Cina hanya berlaku hukum perdata BW dan WvK;

b. Untuk warga negara Timur Asing bukan Cina:

1) Hukum perdata berlaku hukum adat mereka (kecuali yang tunduk pada hukum Eropa);

2) Hukum pidana berlaku WvS.

\footnotetext{
${ }^{25} \mathrm{Yu}$ Un Oppusunggu, 'Arti Penting Hukum Antartata Hukum Untuk Indonesia' (2018) 7 RechtsVinding. [150].

${ }^{26}$ Rika DwiSetiawati, 'Hukum Perdata (Penggolongan Penduduk)' (Wordpress, 2013) < https:/ / rikadwisetiawati.wordpress.com/2013/11/13/hukum-perdata-penggolongan-penduduk-2/ amp/>.accessed 13 Januari 2020.
} 
3) Hukum acara tidak diatur sehingga dapat mengikuti golongan Eropa atau terkadang pribumi

3. Golongan Bumiputera, yang meliputi:

a. Indonesia asli;

b. Keturunan lain yang sudah lama menetap di Indonesia sehingga sudah melebur ke dalam Indonesia asli.

Terhadap golongan ini berlaku :

a. Hukum perdata menggunakan Hukum Adat, BW, WvK untuk beberapa pengecualian;

b. Hukum pidana menggunakan WvS;

c. Hukum acara perdata menggunakan IR (Inlands Reglement), sedangkan hukum acara pidana menggunakan HIR (Herziene Inlands Reglement).

Setelah negara Indonesia merupakan negara kesatuan yang berbentuk republik, maka aturan tersebut sudah tidak berlaku. Saat ini, Indonesia dapat dibedakan secara jelas penduduknya berdasarkan suku, agama, dan ras.

\section{Kriteria Konsep "Antargolongan"}

Pertimbangan hukum hakim dalamPutusan Pengadilan Negeri Jakarta Selatan Nomor 370/Pid.Sus/2018/PN Jkt.Sel (kasus Ahmad Dhani), Putusan Pengadilan Negeri Jakarta Utara Nomor 1105/Pid.Sus/2017/PNJkt.Utr (kasus Muhammad Faizal Tanong), danPutusan Mahkamah Konstitusi Nomor 76/ PUU-XV/2017 tetap tidak dapat memberikan definisi yang jelas mengenai konsep "antargolongan" yang terdapat dalam Pasal 28 ayat (2) UU ITE. Dengan ketiadaan kriteria yang jelas mengenai konsep “antargolongan” dalam Pasal 28 ayat (2) UU ITE, maka seharusnya mencari dan menemukan makna serta kriteria dari konsep "antargolongan" dengan cara melakukan penafsiran sistematis, yaitu penafsiran yang menghubungkan suatu pasal dengan pasal yang lain dalam suatu perundang-undangan yang bersangkutan, dalam hal ini yakni Pasal 156 KUHP.

Pasal 156 KUHP mencakup beberapa entitas menjadi satu istilah yaitu istilah “golongan". Pasal 156 KUHP juga memberikan penjelasan mengenai istilah 
Tiara Kumalasari: Konsep “Antargolongan” dalam...

"golongan" yang dimaksud dalam pasal tersebut yaitu tiap-tiap bagian rakyat Indonesia, yang berbeda dengan suatu atau beberapa bagian lainnya karena rasnya, negeri asalnya, agamanya, tempat asalnya, keturunannya, kebangsaannya atau kedudukannya menurut hukum tata negara.

Dengan penafsiran sistematis, konsep "antargolongan" yang terdapat di dalam Pasal 28 ayat (2) UU ITE dapat dipersamakan dengan istilah "golongan" yang terdapat dalam Pasal 156 KUHP sehingga istilah "antargolongan” dalam Pasal 28 ayat (2) UU ITE itu sendiri sudah mencakup suku, agama, dan ras (SAR).

\section{Kesimpulan}

Berdasarkan pembahasan tersebut, maka dapat disimpulkan bahwa pertimbangan hakim dalam beberapa putusan pengadilan tidak memberikan definisi yang jelas dan cenderung memperluas konsep "antargolongan" pada Pasal 28 ayat (2) Undang-Undang Nomor 19 Tahun 2016 tentang Perubahan Atas Undang-Undang Nomor 11 Tahun 2008 tentang Informasi dan Transaksi Elektronik (UU ITE). Bahkan, dalam Putusan Mahkamah Konstitusi Nomor 76/PUUXV/2017 pun tidak memberikan kejelasan makna dari konsep “antargolongan”.

Kriteria konsep "antargolongan" tidak ditemukan dalam Pasal 28 ayat (2) Undang-Undang Nomor 19 Tahun 2016 tentang Perubahan Atas Undang-Undang Nomor 11 Tahun 2008 tentang Informasi dan Transaksi Elektronik (UU ITE), sedangkan kriteria yang terdapat pada Putusan Mahkamah Konstitusi Nomor 76/PUU-XV/2017 adalah tidak hanya meliputi suku, agama, dan ras, melainkan lebih dari itu yaitu semua entitas yang tidak terwakili atau terwadahi oleh istilah suku, agama, dan ras. Kriteria dalam putusan tersebut masih belum memperjelas makna "antargolongan". Kriteria seperti ini bertentangan dengan prinsip lex certa. Ketidakjelasan ini berimplikasi kepada adanya penafsiran yang berbeda-beda di antara para ahli hukum pidana dan aparat penegak hukum, serta terjadinya penyalahgunaan wewenang dalam praktik penegakan hukum dengan mudahnya menuntut seseorang yang mengeluarkan pendapatnya di media elektronik. 


\section{Daftar Bacaan}

\section{Buku}

Agustinus Pohan, Topo Santoso, dan Martin Moerings, Hukum Pidana Dalam Perspektif (Pustaka Larasan 2012).

Danrivanto Budhijanto, Revolusi Cyberlaw Indonesia Pembaruan dan Revisi UndangUndang Informasi dan Transaksi Elektronik 2016 (PT Refika Aditama 2017).

Didik Endro Purwoleksono, Hukum Pidana: Untaian Pemikiran (Airlangga University Press 2019).

Edmon Makarim, Kompilasi Hukum Telematika(PT RajaGrafindo Persada 2003).

\section{Jurnal}

Yu Un Oppusunggu, 'Arti Penting Hukum Antartata Hukum Untuk Indonesia' (2018) 7 RechtsVinding.

\section{Laman}

Achmad Faizal, ‘Buat Meme Menghina Presiden di Facebook, Seorang Pemuda Ditangkap' (Kompas.com, 2017) <https://regional.kompas.com/ $\mathrm{read} / 2017 / 06 / 09 / 16265591 /$ buat.meme.menghina.presiden.di.facebook. seorang.pemuda.ditangkap>.

Adhi Wicaksono, 'Kaitkan Jokowi dengan Konflik Agraria, Faisol Diciduk Polisi' (CNN Indonesia, 2019) <https://m.cnnindonesia.com/ nasional/20190717131806-12-412902/kaitkan-jokowi-dengan-konflikagraria-faisol-diciduk-polisi>.

Altas Maulana, 'Penghina Presiden Jokowi Divonis 13 Bulan Penjara' (Antaranews. com, 2017) <https://m.antaranews.com/berita/642423/penghinapresiden-jokowi-divonis-15-bulan-penjara>.

AmbaranieNadia Kemala Movanita, “Penulis Buku'JokowiUndercover' Ditangkap dan Ditahan Polisi" (Kompas.com, 2016) <https://nasional.kompas.com/ $\mathrm{read} / 2016 / 12 / 31 / 12423041 /$ penulis.buku.jokowi.undercover.ditangkap. dan.ditahan.polisi>.

Ambaranie Nadia Kemala Movanita, 'Sri Rahayu yang Ditangkap Terkait Konten SARA adalah Anggota Saracen' (Kompas.com, 2017) <https:/ / amp.kompas. com/nasional/read/2017/08/24/10060611/sri-rahayu-yang-ditangkapterkait-konten-sara-adalah-anggota-saracen>. 
Andrian Pratama Taher, 'Mahkamah Agung Tolak Permohonan Kasasi Ahmad Dhani' (Tirto.id, 2019) <https://tirto.id/mahkamah-agung-tolakpermohonan-kasasi-ahmad-dhani-ehdn>.

Anggara Suwahju, "Menakar Makna 'Antargolongan' dalam Pasal 28 (2) UU ITE" (2019) <https://beritagar.id/artikel-amp/telatah/menakar-makna-antargolongan-dalam-pasal-28-2-uu-ite>.

Dian Kurniawan, 'Repdem Jatim Laporkan Dandhy Dwi Laksono Terkait Status di FB' (Liputan6.com, 2017) <https://m.liputan6.com/regional/ $\mathrm{read} / 3085177 /$ repdem-jatim-laporkan-dandhy-dwi-laksono-terkait-statusdi-fb $>$.

Dwi Rizki, 'Kasus Robertus Robet Kini Berstatus dalam Penyidikan' (Wartakota.tribunnews.com, 2019) <https://wartakota.tribunnews.com/ amp/2019/03/12/kasus-robertus-robet-kini-berstatus-dalam-penyidikan>.

Heru Andriyanto, 'Ini Isi Akun Faizal Tonong yang Membuatnya Ditangkap' (Beritasatu.com, 2017) <https://amp.beritasatu.com/nasional/442894/iniisi-akun-faizal-tonong-yang-membuatnya-ditangkap>.

Hestiana Dharmastuti, 'Perjalanan Kasus Ahmad Dhani Hingga Divonis 1,5 Tahun Penjara' (Detiknews, 2019) <https:/ / m.detik.com/news/berita/d-4403919/ perjalanan-kasus-ahmad-dhani-hingga-divonis-15-tahun-penjara>.

Ihsanuddin, 'Penghina Presiden Diproses Polisi, Ini Kata Istana' (Kompas. com, 2017) <https://nasional.kompas.com/read/2017/01/02/16523081/ penghina.presiden.diproses.polisi.ini.kata.istana?page $=2>$.

Ihsan Hidayat, 'Undang-Undang Informatika dan Transaksi Elektronik' (Academia.edu) <https://www.academia.edu/37952527/TUGAS_TI_ ihsan_hidayat_>.

Kiki Andi Pati, 'Diduga Hina Presiden dan Kapolri di Facebook, Seorang Pegawai Kontrak Ditahan' (Kompas.com, 2017) <https://regional.kompas.com/ $\mathrm{read} / 2017 / 06 / 06 / 16232091 /$ diduga.hina.presiden.dan.kapolri.facebook. seorang.pegawai.kontrak.ditahan>.

Kiki Andi Pati, 'Pria Ini Disebut Hina Presiden dan Kapolri di Facebook Sejak 2016' (Kompas.com, 2017) <https://regional.kompas.com/ $\mathrm{read} / 2017 / 06 / 07 / 05463681 /$ pria.ini.disebut.hina.presiden.dan.kapolri. di.facebook.sejak.2016>.

Luthfia Ayu Azanella, 'Selain Ahmad Dhani, Ini Daftar Orang yang Divonis karena Terjerat UU ITE' (Kompas.com, 2019) <https://nasional.kompas. 
com/read/2019/01/30/18493331/selain-ahmad-dhani-ini-daftar-orangyang-divonis-karena-terjerat-uu-ite?page $=3>$.

Masfiatur Rochma, 'Samakan Megawati dengan Aung San Suu Kyi, Dandhy Dwi Laksono Dipolisikan' (Merdeka.com, 2017) <https://m.merdeka.com/ amp/peristiwa/samakan-megawati-dengan-aung-san-suu-kyi-dandhydwi-laksono-dipolisikan.html>.

Rika Dwi Setiawati, 'Hukum Perdata (Penggolongan Penduduk)' (Wordpress, 2013) <https://rikadwisetiawati.wordpress.com/2013/11/13/hukumperdata-penggolongan-penduduk-2/amp/>.

Yandri Daniel Damaledo, 'Kasus-Kasus Hukum yang Pernah Menjerat Ahmad Dhani' (Tirto.id, 2019) <https://amp.tirto.id/kasus-kasus-hukum-yangpernah-menjerat-ahmad-dhani-dfiB $>$.

\section{Perundang-undangan}

Undang-Undang Republik Indonesia Nomor 19 Tahun 2016 tentang Perubahan Atas Undang-Undang Nomor 11 Tahun 2008 tentang Informasi dan Transaksi Elektronik(Tambahan Lembaran Negara Republik Indonesia Nomor 5952, Tambahan Lembaran Negara Republik Indonesia Nomor 5952).

How to cite: Tiara Kumalasari, 'Konsep “Antargolongan” dalam Pasal 28 Ayat (2) Undang-Undang Nomor 19 Tahun 2016 Tentang Perubahan atas Undang-Undang Nomor 11 Tahun 2008 Tentang Informasi Dan Transaksi Elektronik (UU ITE)' (2020) Vol. 3 No. 2 Media Iuris. 
--Halaman ini sengaja dibiarkan kosong-- 